\title{
ANALISA POLA PERJALANAN TRANSPORTASI PENDUDUK DAERAH PINGGIRAN (STUDI KASUS : DESA MURNISARI KECAMATAN MANDE KABUPATEN CIANJUR)
}

\author{
${ }^{1}$ Yudi Sekaryadi, ${ }^{2}$ Siti Saptiani Putri, ${ }^{3}$ Devi Setiawan \\ Program Studi Teknik Sipil Fakultas Teknik Universitas Suryakancana \\ yudisekaryadi65@gmail.com,saptianiputri96@gmail.com
}

\begin{abstract}
Abstrak
Desa Murnisari adalah salah satu desa yang berada di kecamatan Mande. Daerah ini terletak di pinggiran kecamatan Mande, akses menuju daerah tersebut cukup sulit dilalui kendaraan karena kondisi jalannya yang buruk. Jarak yang ditempuh untuk menuju kota cukup jauh sekitar 5-7 km, kendaraan yang dapat masuk kedaerah ini hanya kendaraan pribadi dan kendaraan umum seperti ojeg. Penelitian tentang analisa pola perjalanan ini menggunakan dua variabel yang disusun dalam sebuah kuesioner yang dijabarkan dalam beberapa pertanyaan yang disebar kepada masyarakat yang ada didaerah tersebut dengan memperhatikan tiga golongan yang dianalisa diantaranya, ibu rumah tangga, pekerja, dan pelajar. Ketiga golongan tersebut diharapkan mewakili pendapat seluruh masyarakat. Metode yang digunakan dalam penelitian ini yaitu dengan uji validitas dan reabilitas yang diolah dengan menggunakan aplikasi SPSS. Berdasarkan hasil analisis menggunakan aplikasi SPSS, kedua variabel yang dianalis hasilnya valid dengan nilai yang berbeda. Namun hasilnya $r$ hitung > $r$ tabel jadi semua pertanyaan dari dua variabel itu valid sehingga bisa diterapkan di daerah itu. Setelah uji validitas dilakukan selanjutnya dilakukan uji korelasi dimana dalam tahap ini penulis mencari hubungan antara setiap variabel. Jeniskorelasiyang dipakai yaitu korelasi Rank Spearman dimana jenis korelasi ini sangat tepat dipakai untuk penelitian yang dilakukan.Solusi yang tepat untuk seluruh varibel yaitu dengan cara memperbaiki akses jalan menuju daerah tersebut dengan begitu masyarakat akan lebih mudah melakukan perjalanan ke kota maupun sebaliknya. Dengan begitu segi perekonomian dan pendidikan masyarakat di daerah tersebut akan jauh lebih baik lagi.
\end{abstract}

Kata kunci : Validitas, Reabilitas, Korelasi, SPSS

\section{PENDAHULUAN}

Kegiatan pembangunan kota merupakan suatu rangkaian yang tidak dapat dipisahkan dari kegiatan pembangunan secara keseluruhan dalam kerangka ruang dan waktu. Hal ini terjadi karena adanya tuntutan kebutuhan yang selalu timbul berupa perkembangan kota yang berhubungan dengan perkembangan penduduk serta aktivitas atau kegiatan yang dilakukannya serta hubungannya dengan perkembangan daerah lainnya. Kota dipandang sebagai suatu obyek studi dimana didalamnya terdapat masyarakat manusia yang sangat komplek (Yunus, 2004). Teori model Harris - llman menyebutkan bahwa zone tempat tinggal di daerah pinggiran membentuk komunitas tersendiri dalam artian lokasinya. Penduduk di daerah pinggiran sebagian besar bekerja di pusat pusat kota dan zone ini semata - mata digunakan untuk tempat tinggal.
Ketika pemikiran diarahkan ke masa yang akan datang dimana kawasan perumahan di pinggiran kota yang semula sepi akan berkembang pesat menjadi kawasan perumahan yang padat penduduknya sedangkan pada sisi lain prasarana jalan yang dibangun pemerintah perkembangannya sangat kecil. Oleh karena itu pentingnya usahausaha perencanaan guna mengantisipasi perkembangan daerah pinggiran kota Cianjur terutama terkait dengan masalah transportasi. Melalui penelitian ini akan diberikan gambaran mengenai pola perjalanan transportasi penduduk di daerah pinggiran kota Cianjur (Kecamatan Mande, yakni Desa Murnisari ).

Lokasi atau daerah yang dipilih untuk penelitian ini adalah di Kecamatan Mande, tepatnya Desa Murnisari tersebut terletak di daerah pinggiran kota Cianjur dan melalui penelitian ini akan diketahui pola perjalanan transportasi dari penduduk di daerah pinggiran kota Cianjur. 


\section{TINJAUAN PUSTAKA}

\section{A. Pemilihan Lokasi Hunian}

a) Dimensi lokasi Dimensi ini mengacu pada tempat - tempat tertentu pada suatu kota yang oleh seseorang / sekelompok orang dianggap paling cocok untuk tempat tinggal.

b) Dimensi perumahan Dimensi perumahan dikaitkan dengan aspirasi perorangan / sekelompok orang terhadap macam, tipe perumahan yang ada. Pandangan seseorang terhadap aspek penguasaan tempat tinggal selalu dikaitkan dengan tingkat penghasilan dan siklus kehidupannya.

c) Dimensi siklus kehidupan Membahas tahap tahap seseorang mulai menapak dalam kehidupan mandirinya, dalam artian bahwa semua kebutuhan hidupnya seratus persen ditopang oleh penghasilannya sendiri.

d) Dimensi penghasilan Dimensi ini menekankan pembahasannya pada besar kecilnya penghasilan yang diperoleh per satuan waktu.

\section{B. Pembagian Ruang Kota}

Menurut E.W. Burgess suatu kota akan terdiri dari zona - zona konsentris dan masing - masing zona ini mencerminkan tipe lahan yang berbeda. Pada suatu kota biasanya terdapat Daerah Pusat Kegiatan (DPK) yang merupakan pusat kehidupan sosial, ekonomi, budaya dan politik sehingga pada zona ini terdapat bangunan utama untuk kegiatan sosial, ekonomi, budaya dan politik. Rute - rute transportasi dari segala penjuru

\section{Persebaran Ruang Sosial Konsentris}

a) Familisme Orang yang belum menikah akan mempunyai selera lokasi dan jenis tempat tinggal yang berbeda dengan orang yang sudah menikah. Orang yang sudah menikah tetapi belum punya anak akan berbeda pula dengan yang sudah menikah dan punya anak.

b) Konsumerisme Variasi kemampuan untuk membayar ternyata sejalan pula dengan preferensi lokasi dan jenis tempat tinggal.

c) Karirisme Bagi mereka yang cenderung menekankan gaya hidupnya pada kerja (karirisme) akan lebih menyukai lokasi tempat tinggal dekat dengan pusat kota karena daerah inilah yang merupakan pusat kegiatan kota dan identik dengan lapangan kerja.

\section{METODOLOGI}

penelitian adalah suatu proses mencari sesuatu secara sistematik dalam waktu yang lama dengan menggunakan metode ilmiah serta aturan - aturan yang berlaku. Untuk menerapkan metode ilmiah dalam praktek penelitian maka diperlukan suatu desain penelitian yang sesuai dengan kondisi.

Desain dalam penelitian ini adalah penelitian kualitatif yaitu penelitian yang berfokus pada pengalaman, interpretasi serta makna hidup seseorang yang mengalaminya (Moleong,2004). Jenis data yang digunakan dalam penelitian kualitatif yaitu data yang diungkapkan dalam bentuk kalimat serta uraian.

\section{A. Jenis Dan Desain Penelitian}

Nama : Desa Murnisari Kecamatan Mande, Cianjur Alamat : (Kp.Cikowak, Cibarengkok, Sawahbra, Margaluyu, Babakangempol, Pasir Kelewih) Waktu Penelitian : Maret 2019 - Juli 2019

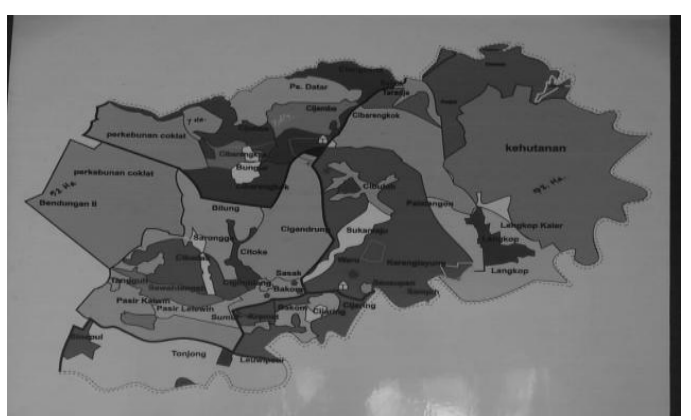

Gambar 1 Peta Lokasi Penelitian

Metode yang digunakan dalam penelitian ini yaitu menggunakan kuisioner atau angket dan dilanjutkan dengan menghitung dengan menggunakan aplikasi yaitu SPSS.

\section{PEMBAHASAN}

\section{A. Data Penelitian}

data yang didapat diperoleh dari responden yang disebar. Dari 3343 jiwa warga yang terdapat di Desa ini, dibagi menjadi tiga golongan (3) yaitu Pelajar, Pekerja dan Ibu Rumah Tangga. Mengapa hanya tiga golongan yang dianalisis,itu karena di Desa ini warga yang melakukan perjalanan yang bisa dibilang cukup jauh hanya tiga golongan tersebut.

1. Pekerja

Dari jumlah seluruh warga kurang lebih 3343 jiwa, ada sebanyak kurang lebih $30 \%$ yang termasuk kepada golongan pekerja. Itu berarti jumlah pekerja di Desa ini mencapai 1002 orang yang bekerja. Pekerjaanya bermacam-macam, ada yang bekerja di sawah,toko,pabrik, dan lain sebagainya.

2. Pelajar

Pelajar di daerah ini cukup banyak jumlahnya, akan tetapi pada penelitian kali ini jumlah pelajar yang diperhitungkan adalah pelajar yang notabene melakukan perjalanan menggunakan transportasi 
baik pribadi maupun umum. Jumlah sarana pembelajaran seperti sekolah SD,SMP/MTS, MA/SMA sebetulnya di daerah ini pun ada, namun memerlukan waktu tempuh yang cukup lama dan jalan yang dilalui pun bisa dibilang belum layak. yakni jumlahnhya $0,29 \times 312=90,48 \rightarrow 91$ orang. 3. Ibu rumah tangga

Jumlah ibu rumah tangga di daerah ini mencapai kurang lebih $41 \%$, jumah itu dilihat dari banyaknya ibu rumah tangga baru mapun yang sudah usia lanjut. Iburumah tangga baru yang dimaksud adalah perempuan muda yang baru saja menikah. Selanjutnya untukpenentuan sampel diketahui bahwa jumlah ibu rumah tangg jumlahnya $41 \%$, berarti $0,41 \times 312=127,92 \rightarrow 128$ orang.

Pada variabel ini responden diberikan beberapa pernyataan yang harus diisi oleh responden berdasarkan pilihan hati nurani dari responden itu sendiri. Pernyataan pada variabel ini berjumlah 10 pernyataan yang berisikan mengapa menggunakan transportasi pribadi atau umum, dan beberapa alasan yang mewakili pendapat warga sekitar atas sarana transportasi baik dari segi jalan, kendaraan, kondisi badan dan lain-lain.

\section{B. Hasil Analis Menggunakan SPSS}

Tabel 1. Analisis Uji Validitas Dan Reliabilitas Ibu Rumah Tangga

\begin{tabular}{lllll}
\hline & & & & \\
& $\begin{array}{l}\text { Frequen } \\
\text { cy }\end{array}$ & $\begin{array}{l}\text { Percen } \\
\mathrm{t}\end{array}$ & $\begin{array}{l}\text { Valid } \\
\text { Percent }\end{array}$ & $\begin{array}{l}\text { Cumula } \\
\text { tive } \\
\text { Percent }\end{array}$ \\
TB & 5 & 3,9 & 3,9 & 3,9 \\
KB & 36 & 28,1 & 28,1 & 32,0 \\
CB & 50 & 39,1 & 39,1 & 71,1 \\
B & 34 & 26,6 & 26,6 & 97,7 \\
SB & 3 & 2,3 & 2,3 & 100,0 \\
Total & 128 & 100,0 & 100,0 & \\
\hline
\end{tabular}

\section{Scale: ALL VARIABLES}

Case Processing Summary

\begin{tabular}{llll} 
& & $\mathrm{N}$ & $\%$ \\
Cases & Valid & 128 & 100,0 \\
& Excluded $^{\mathrm{a}}$ & 0 &, 0 \\
& Total & 128 & 100,0 \\
\hline
\end{tabular}

\begin{tabular}{|c|c|}
\hline \multicolumn{2}{|c|}{ Reliability Statistics } \\
\hline $\begin{array}{l}\text { Cronbac } \\
\text { h's Alpha }\end{array}$ & $\mathrm{N}$ of Items \\
\hline 718, & 20 \\
\hline
\end{tabular}

Tabel 2. Data Hasil Analis Uji Validasi Dan Reabilitas Pelajar

\begin{tabular}{llllll}
\hline $\mathbf{x}$ & & $\begin{array}{l}\text { Frequ } \\
\text { ency }\end{array}$ & Percent & $\begin{array}{l}\text { Valid } \\
\text { Percent }\end{array}$ & $\begin{array}{l}\text { Cumul } \\
\text { ative } \\
\text { Percen } \\
\text { t }\end{array}$ \\
Val & TB & 4 & 4,4 & 4,4 & 4,4 \\
id & KB & 10 & 11,0 & 11,0 & 15,4 \\
& CB & 40 & 44,0 & 44,0 & 59,3 \\
& KB & 23 & 25,3 & 25,3 & 84,6 \\
& SB & 14 & 15,4 & 15,4 & 100,0 \\
& Total & 91 & 100,0 & 100,0 & \\
\hline
\end{tabular}

Scale: ALL VARIABLES

\begin{tabular}{llll}
\hline \multicolumn{3}{l}{ Case Processing Summary } & \\
Cases & $\mathrm{N}$ & $\%$ \\
& Valid & 91 & 100,0 \\
& Excluded $^{\mathrm{a}}$ & 0 &, 0 \\
& Total & 91 & 100,0 \\
\hline
\end{tabular}

\begin{tabular}{ll}
\hline Reliability Statistics & \\
Cronbach's Alpha & N of Items \\
, 470 & 20 \\
\hline
\end{tabular}

Tabel 3. Data Hasil Analis Uji Validitas Dan Reabilitas Pekerja

\begin{tabular}{lllll}
\hline $\mathbf{X}$ & & & & \\
& $\begin{array}{l}\text { Freque } \\
\text { ncy }\end{array}$ & $\begin{array}{l}\text { Perce } \\
\text { nt }\end{array}$ & $\begin{array}{l}\text { Valid } \\
\text { Percent }\end{array}$ & $\begin{array}{l}\text { Cumula } \\
\text { tive } \\
\text { Percent }\end{array}$ \\
TB & 5 & 5,3 & 5,3 & 5,3 \\
KB & 19 & 20,2 & 20,2 & 25,5 \\
CB & 34 & 36,2 & 36,2 & 61,7 \\
B & 21 & 22,3 & 22,3 & 84,0 \\
SB & 15 & 16,0 & 16,0 & 100,0 \\
Total & 94 & 100,0 & 100,0 & \\
\hline
\end{tabular}


Scale: ALL VARIABLES

\begin{tabular}{|c|c|c|c|}
\hline \multicolumn{4}{|c|}{ Case Processing Summary } \\
\hline & & $\mathrm{N}$ & $\%$ \\
\hline \multirow[t]{3}{*}{ Cases } & Valid & 94 & 100,0 \\
\hline & Excluded $^{a}$ & 0 & ,0 \\
\hline & Total & 94 & 100,0 \\
\hline \multicolumn{4}{|c|}{ Reliability Statistics } \\
\hline \multirow{2}{*}{\multicolumn{3}{|c|}{ Cronbach's Alpha }} & $\mathrm{N}$ of Items \\
\hline & & & 20 \\
\hline
\end{tabular}

C. Uji Korelasi Dengan Menggunakan Metode Rank Spearman

Merupakan bagian dari statisik nonparametrik (tidak memerlukan asumsi normalitas dan linearitas)

a) Bertujuan untuk mengetahui hubungan antar variabel

b) Arah hubungan antar variabel bisa bersifat positif dan negatif.

c) Data penelitian berbentuk peringkat sehingga disebut korelasi rank spearman.

d) Tidak ada istilah variabel bebas (x) maupun variabel terkait (y)

Penafsiran analisis korelasi

a) Melihat signifikansi hubungan

b) Melihat kekuatan hubungan.

c) Melihat arah hubungan

Tabel 4. Nilai Ranking Metode Rank Spearman

\begin{tabular}{|c|c|}
\hline Nilai & Makna \\
\hline $0,00-0,25$ & $\begin{array}{l}\text { Sangat rendah / sangat } \\
\text { lemah }\end{array}$ \\
\hline $0,26-0,50$ & Rendah / Lemah \\
\hline $0,51-0,75$ & Sedang \\
\hline $0,76-0,99$ & Tinggi / Kuat \\
\hline 1,00 & Sangat Tinggi / Kuat \\
\hline
\end{tabular}

Tabel 5. Uji Korelasi Golongan Ibu Rumah Tangga

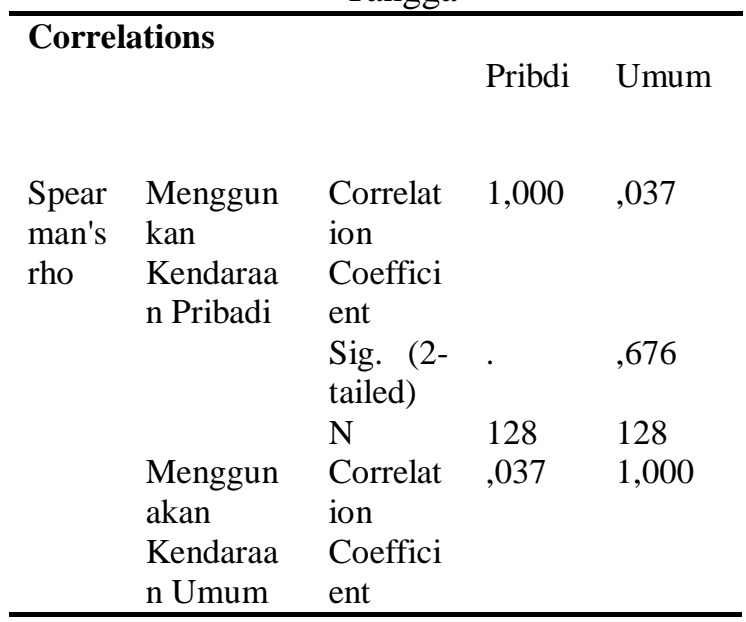

\begin{tabular}{llll}
\hline $\begin{array}{l}\text { Sig. }(2- \\
\text { tailed })\end{array}$ &, 676 & $\cdot$ \\
$\mathrm{N}$ & 128 & 128 \\
\hline
\end{tabular}

Tabel 5. Uji Korelasi Golongan Ibu Rumah Pekerja

\begin{tabular}{|c|c|c|c|}
\hline \multicolumn{4}{|l|}{ Correlations } \\
\hline & & Pribdi & Umum \\
\hline \multirow{4}{*}{$\begin{array}{l}\text { Menggunak } \\
\text { an } \\
\text { kendaraan } \\
\text { Pribadi }\end{array}$} & Correlation & 1,000 & , 106 \\
\hline & Coefficient & & \\
\hline & $\begin{array}{l}\text { Sig. } \\
\text { tailed) }\end{array}$ & . & ,307 \\
\hline & $\mathrm{N}$ & 94 & 94 \\
\hline \multirow{4}{*}{$\begin{array}{l}\text { Menggunak } \\
\text { an } \\
\text { Kendaraan } \\
\text { Umum }\end{array}$} & Correlation & , 106 & 1,000 \\
\hline & Coefficient & & \\
\hline & Sig. & ,307 & \\
\hline & tailed) & & 04 \\
\hline
\end{tabular}

Tabel 6. Uji Korelasi Golongan Ibu Rumah Pelajar

\section{Correlations}

Pribadi Umum

\begin{tabular}{llll}
$\begin{array}{l}\text { Mengguna } \\
\text { kan }\end{array}$ & $\begin{array}{l}\text { Correlation } \\
\text { Coefficient }\end{array}$ & 1,000 &,- 079 \\
Kendaraan & Sig. (2-tailed) &. &, 457 \\
Pribadi & N & 91 & 91 \\
Mengguna & Correlation &,- 079 & 1,000 \\
kan & Coefficient & & \\
Kendaraan & Sig. (2-tailed) &, 457 &. \\
Umum & N & 91 & 91 \\
\hline
\end{tabular}

\section{KESIMPULAN DAN SARAN}

A. Kesimpulan

1. semua variabel pada setiap golongan dinyatakan valid dan hasil reabilitasnya diatas nilai $r$ hitung yang ada pada tabel $r$. Itu artinya bahwa ketiga golongan yang diteliti bisa menggunakan kendaraan pribadi ataupun umum.

2. Maka dari itu bisa disimpulakan bahwa ketiga golongan diatas dapat menggunakan kedua variabel yang diteliti yaitu menggunakan kendaraan umum atau pribadi.

3. Nilai signifikansi sebesar 0,676 berarti lebih besar dari 0,05 yang artinya tidak signifikan. Lalu untuk arah hubungannya yaitu + ( positif ) yang artinya data yang diuji searah maksud dari searah adalah meningkatnya penggunaan kendaraanpribadi juga meningkat pula penggunaan kendaraan umum. namun pada 
kenyataannya timbul beberapa maslah yaitu diantaranya :

- Prasarana Jalan yang rusak / tidak layak

- Biaya yang mahal jika menggunakan kendaraan umum

- Keberadaan kendaraan umum yang ada di lingkungan desa ini

- Tingkat perekonomian masyarakat yang masih rendah

\section{B. Saran}

1. Untuk menambah nilai perekonomian warga sekitar maka prasarana jalan harus diperbaiki supaya warga lain yang ingin datang berkunjung tidak bermasalah dengan jalannya, dan warga sekitar yang ingin bepergian pun akan sangatmudah dan cepat.

2. Persilahkan kendaraan umum untuk datang kedaerah ini supaya warga dalam melakukan aktifitasnnya akan lebih mudah.

3. Berikan biaya yang sesuai untuk pengguna transportasiumum supaya minat menggunakan transportasi umum akan lebih meningkat.

\section{DAFTAR PUSTAKA}

Alviansyah \& soehodho, S., 1997, Dasar Sistem Transportasi, Laboratorium Transportasi Jurusan Teknik Sipil Universitas Indonesia, Jakarta.

Morlok, A.J., 1988, Pengantar Teknik Perencanaan Transportasi, Penerbit Erlangga, Jakarta Pusat.

Sugiyono,2005, Statistika Untuk Penelitian, Alfabeta, Bandung.

Tarmin, O.Z., 1997, Perencanaan dan Permodelan Transportasi, Institut Teknologi Bandung.

Yunus, H.S.,2004, Stuktur Tata Ruang Kota, Penerbit Pustaka Pelajar Offset, Yogyakarta.

Nazir, M., 1983, Metodologi Penelitian, Penerbit Ghalia Indonesia, Jakarta.

Kementerian Pekerjaan Umum, 2012, SNI-28472013 Persyaratan Beton Struktural Untuk Bangunan Gedung. Bandung.

https://andisucahyoblog.wordpress.com/pengertia n-fungsi-manfaat-dan-jenis-jenis transportasi/) Diakses tgl 20 februari 2019

http://soegengpoernomo.blogspot.com/2015/03/def inisi-transportasi-menurut-para-ahli.html) Diakses tgl 20 februari 2019 